\title{
ПЕРЕКЛАДАЦЬКІ ТРАНСФОРМАЦІЇ У ПРОЦЕСІ ВІДТВОРЕННЯ ЕМОЦІЙНО-ОЦІННОЇ ЛЕКСИКИ В АУДІОВІЗУАЛЬНОМУ ПЕРЕКЛАДІ СЕРІАЛУ «БРІДЖЕРТОНИ»
}

\begin{abstract}
Анотація. Запропонована стаття присвячена дослідженню особливостей застосування перекладацьких трансформацій у процесі відтворення емоційно-оцінної лексики в аудіовізуальному перекладі американського серіалу «Бріджертони» українською мовою. Аудіовізуальний переклад трактуеться фахівцями як переклад вербального супроводу до відеоряду з метою забезпечення такого самого впливу на реципієнта, який справляе оригінальний текст. Під емоційно-оцінною лексикою ми розуміемо таку, яка позначае почуття, емоції, настрій та ставлення мовця до об'єктів навколишнього світу. У процесі відтворення емоційно-ощінної лексики американського серіалу «Бріджертони» українською мовою спостерігається використання значної кількості перекладацьких трансформацій, серед яких кількісно переважають заміни (60\%). Вилучення складають $28 \%$, перестановки - 9,2\%, додавання - 2,8\%. Серед замін $(60 \%)$ переважають граматичні заміни $(22,2 \%) ; 21,7 \%$ складае прийом компенсації, $8,7 \%$ - лексичні заміни, $7,4 \%$ - антонімічний переклад.
\end{abstract}

Ключові слова: аудіовізуальний переклад, емоційно-оцінна лексика, перекладацькі трансформації, серіал «Бріджертони», таймінг.

Mykytiuk Iryna, Atitian Andriiana Yuriy Fedkovych Chernivtsi National University

\section{TRANSLATION TRANSFORMATIONS IN THE PROCESS OF EMOTIONAL EVALUATIVE VOCABULARY RENDERING IN AUDIOVISUAL TRANSLATION OF A DRAMA SERIES «BRIDGERTON»}

Summary. The topicality of the presented article is stipulated by an active interest of modern linguists in the issues of audiovisual translation investigation and emotional evaluative vocabulary rendering as the number of serials in English is constantly rising and the necessity for their adequate translation is continuously increasing. The novelty of our research lies in the fact that an attempt to analyze peculiar techniques of rendering emotional evaluative vocabulary used in a popular Netflix drama series Bridgerton (2020) has been made for the first time. The tasks of the given article are to define audiovisual translation and to analyze translation transformations used in the process of rendering emotional evaluative vocabulary in audiovisual translation of the Bridgerton series. The investigation is based on 739 emotional evaluative lexemes singled out from 8 episodes of Season 1 Netflix drama series Bridgerton (2020) and their translations into Ukrainian by HDrezka Studio. The findings obtained in the result of quantitative and contrastive analyses allow us to conclude that in the course of audiovisual translation of emotional evaluative vocabulary in the Bridgerton series, various translation transformations have been employed. The key one is transposition which makes up $60 \%$ of all the transformations. Next in quantity is omission which comprises $28 \%$, followed by replacement / permutation $(9,2 \%)$ and addition (2,8\%). Within transposition (60\%) grammatical transposition prevails $(22,2 \%)$; compensation makes up $21,7 \%$, lexical transposition $-8,7 \%$, antonymic translation $-7,4 \%$. This may be explained by the necessity to ensure the analogous effect from the translation as is meant by the original audiovisual text or product, as well as to avoid redundancy. Furthermore, the translator's choice is influenced by both linguistic (analytical type of English and synthetical one of Ukrainian) and extralinguistic factors, as well as other limitations such as timing and preservation of articulation. The prospects of further research may be connected with investigation of gender aspect of translation transformations in audiovisual translation of the drama series Bridgerton or the study of techniques for rendering emotional evaluative lexis in another audiovisual or printed text.

Keywords: audiovisual translation, emotional evaluative vocabulary, translation transformations, drama series Bridgerton, timing.

$\Pi$ остановка проблеми. Завдяки процесу глобалізації та стрімкому розвитку цифррових технологій, все більшої популярності сьогодні набуває новий напрямок перекладознавства - аудіовізуальний переклад.

Беручи до уваги синтетичну природу кіномистецтва, Н. А. Матківська стверджує, що «переклад аудіовізуальної продукції направлений на одночасну матеріалізацією як вербальних/невербальних структур (діалоги, коментарі, жестикуляція), так і візуально-звукових компонентів (загальна атмосфрера відеосюжетів)» [3, с. 148].
Аналіз останніх досліджень і публікацій. Питання перекладу аудіовізуальної продукції, його особливостей та проблем виступали об'єктом дослідження як вітчизняних, так і зарубіжних науковців, зокрема Л. Богуцького, Е. Бруздзяк, В. Горшкової, М. Вербицької, Г. Денисова, І. Гамбієр, Г. Готліб, Г. Люкен, П. Ореро, Л. Перез-Гонзалес, А. Ремель, Дж. Д. Сандерсон та інших.

Останнім часом питанням емоційності та оцінності приділяється все більше уваги в мовознавчих студіях: дослідники відносять цю проблему до першочергових завдань антропоцентричної

${ }^{1}$ ORCID: https://orcid.org/0000-0003-4502-7605 
лінгвістики (праці Ю. Д. Апресяна, О. М. Вольф, А. М. Гладкової, В. М. Телії, В. І. Шаховського, А. Вежбицької та ін.).

Особливості використання у мовленні емоційно-оцінної лексики та шляхи її трансляції мовою перекладу вивчалися такими мовознавцями як: C. С. Срмоленко, який описував процеси меліорації тексту оригіналу в художньому перекладі; Н. А. Лук'янова, яка розглядала семантику i фоункції експресивних одиниць; Н. Бойко, яка виокремила семантичний, лексикографрічний i фрункціональний аспекти експресивних одиниць. На емоційно-оцінних назвах осіб у системі художніх зображальних засобів мови зосереджувала увагу Л. П. Жаркова.

Виділення не вирішених раніше частин загальної проблеми. Аналіз особливостей відтворення емоційно-оцінної лексики на матеріалі аудіовізуального перекладу нового популярного американського костюмованого серіалу від Netflix «Бріджертони» (2020р.) українською мовою ще не проводився, в чому вбачаємо новизну нашого дослідження.

Метою статті $€$ виявлення особливостей перекладу емоційно-оцінної лексики у процесі аудіовізуального перекладу серіалу «Бріджертони».

Виклад основного матеріалу. Як відомо, серіал - це аудіовізуальний твір, що складається 3 багатьох частин (серій), які можуть бути об'єднані спільною темою. Розглянемо основні характеристики американського костюмованого серіалу від Netflix «Бріджертони».

Після своєї прем'єри на Різдво, 25 грудня 2020 , серіал став миттево популярним і отримав 82 мільйони переглядів за перший місяць від дня релізу. Про це повідомляе Kyiv Live 3 поси-

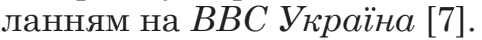

Сюжет серіалу відтворює альтернативну реальність життя початку XIX століття, схожу на романи Джейн Остін через свою консервативність та канони, які не можна порушувати юним леді. За сюжетом, представники аристократичної лондонської родини Бріджертонів вирізняються своїм розумом і красою. Та коли настає час для заміжжя старшої доньки Дафони, популярність цієї родини може або різко похитнутись, або ж стрімко злетіти, що залежатиме від чуток, які поширюються завдяки лондонській пліткарці леді Віслдаун. Ця леді не боїться розповсюджувати «новини» навіть про їі величність королеву, зберігаючи при цьому повну анонімність [4].

Незважаючи на любовну сюжетну лінію, яка переважає, у серіалі також порушуеться низка важливих соціальних питань: боротьба за права жінок, расова дискримінація, фремінізм (Елоїза мріе навчатися в університеті та бути письменницею), проблеми у королівській сім'і.

Зазначимо, що багато глядачів незадоволені появою темношкірих акторів у серіалі і вважають це свідченням історичної недостовірності картини: королева Шарлотта, лорд Гастінгс, його тітка, фрейліни зображені темношкірими, що було б неприпустимим на той час. Однак, це прояв політики толерантності Netflix.

Багато елементів культури відтворені правильно, однак костюми героїв піддаються нищівній критиці за свою невідповідність моді початку XIX ст., особливо через яскраві кольори суконь дівчат родини Фезерінгтон. Проте, такі культурні аспекти, як бокс на кулаках та азартні ігри повністю відбивають бум тієї епохи.

Відгуки глядачів щодо україномовного перекладу є переважно схвальними (Дубляж супер! Дуже вдячна за нереально крутий дубляж українською. Окрела подяка за украӥнський переклад . Це як мед для вух. Але переклад хороший! Щиро дякую за украӥнськоловний дубляж! Душа радіє))) дякую за дуже якісне озвучення украӥнською! тощо [8]).

Проаналізуємо перекладацькі трансформації, застосовані у процесі аудіовізуального перекладу емоційно-оцінної лексики для досягнення їі адекватного відтворення.

У пращі «Мова та переклад» Л. Бархударов наводить таку класифікацію трансформацій: «1) перестановки: зміна порядку розташування компонентів складного речення, а також зміна місця слів і словосполучень; 2) заміни: компенсація, синтаксичні заміни в структурі складного речення, заміна частин мови, компонентів речення та словоформи, заміна причини на наслідок (і навпаки), конкретизація, генералізація, членування і об'єднання речень, антонімічний переклад; 3) вилучення; 4) додавання» [1, с. 190]. Науковець також зазначає, що згадані вище перекладацькі трансформації, зазвичай, комбінуються. Саме цієї класифрікації будемо дотримуватися у цій розвідці.

Розглянемо трансорормації у процесі аудіовізуального перекладу 739 одиниць емоційнооцінної лексики детальніше.

Перестановка. Перекладач може змінювати порядок слів або словосполучень, частин речення або цілих речень у тексті. Нами було виявлено 23 випадки перестановки порядку слів, 45 перестановки частин речення.

Одинадцять прикладів перестановки порядку слів пов'язано з уживанням в англійській мові присвійного відмінку (possessive case), наприклад: "A glimmer of displeasure ... and a young lady's value plummets to unthinkable depths" [5]"Натяк на невдоволення ... i иінність юної леді паде на сале дно" [8]; "She has named Daphnе as the season's Incomparable" [5] - "Вона пише, шо Даббні ббаворитка сезону" [8].

Серед перестановок частин речення спостерігаємо інверсію (перестановка підмета та присудка): "But as we know, the brighter a lady shines, the faster she may burn" [5] - Але ви знаєте, шо чил яскравіше сяє леді, тил швидше вона ложе 3горітu"' [8].

Також обставина або додаток може вільно пересуватися на початок або середину речення: "Mary Edgecombe wore a similar shade last season" [5] - "B Мері Еджкоул линулого сезону був подібний відтінок" [8]; "I can think of worse matches for Daphne than a duke" [5] - "Гepиог не найгірша партія для Даббни» [8].

Це пов'язано з тим, що в українській мові порядок слів не є фріксованим.

Заміни, за спостереженнями А. В. Мамрак, полягають у вживанні одніеї мовної одиниці замість іншої і бувають граматичними (форма слова, частина мови, члени речення, типи речення) та лексичними (конкретизація, генералізація). До замін також відносяться антонімічний пере- 
клад та компенсація [2, с. 108-111]. Наведемо приклади кожного типу замін.

Граматичні заміни. Розпочнемо аналіз граматичних замін у перекладі емощійно-оцінної лексики 3 форм множини/однини іменника, які замінюються на відповідно однину/множину. Таких замін ми виявили 56, наприклад: "Every eligible lady of breeding dressed in some lavishly trimmed frock, bloodthirsty mamas at their side and wary fathers making arrangements for only the most advantageous of matches" [5] - "Дівиuл в якісь недолугій сукні, біля неї їі кровожерна миатуся і насторожений татусь, ретельно підбирають їй пару" [8].

3 прикладу ми бачимо, що емощійно-ощінні сполучення прикметників та іменників в формі множини були замінені перекладачем на відповідну форму однини: "bloodthirsty mamas" - «кровожерна матуся", "wary fathers" - "насторожений mamycb", "the most advantageous of matches - napy".

Приклад заміни однини на множину спостерігаємо у наступному фррагменті: "Every presumptuous mother in town will leave me alone, and every suitor will be looking at you" [5] - "Кожна матуся в місті дасть мені спокій, а всі наречені дивитилуться на вас" [8].

Словосполучення "every suitor" відтворено відповідником "всі наречені", що звучить природніше мовою перекладу, ніж можливе «кожен наречений".

Однак, найбільше замін виявлено нами серед частин мови - 80 прикладів:

- прикметник $\rightarrow$ дієслово: "Indeed, a love as pure as what Mama and Papa once shared, if we are so fortunate" [5] - "Така чиста, як в тата з малою, якщо нам пощастить" [8]; "I'm quite parched" [5] - "Мені хочеться numu" [8];

- прикметник $\rightarrow$ іменник: "She has named Daphne as the season's Incomparable" [5] - "Вона пише, шо Даббні ббаворитка сезону" [8]; "Yои are known to be quite charitable" [5] - "Bu вidoлna благодійниця" [8];

- іменник $\rightarrow$ дієслово: "If you desired an introduction, madam, I do believe accosting me to be the least civilized of ways" [5] - "Якщо хочете noзнайолитися, то так чіплятися не найбільш иивілізований спосіб" [8]; "It seems our diamond requires a closer inspection" [5] - "Здається, до нашого діаланту треба придивитися ближче» [8];

- іменник $\rightarrow$ прислівник: "These pages certainly report on the viscountess's family with much indulgence, indeed" [5] - "Ha uux cmopiнках дуже схвально відгукуються про родину віконтесси" [8].

Приклад нижче ілюструє цікаве рішення перекладача, який 3 невідомих причин змінив граматичний час усього речення 3 минулого на майбутній, хоча дія (візит до королеви) вже відбулася: "simpered and minced - буду". До того ж, бачимо модуляцію значення цих дієслів: їхні словникові еквіваленти $е$ відповідно «удавано посміхатися» та «дріботіти (швидко йти дрібними кроками)»: "I merely simpered and minced in a pretty dress like everyone else» [5] - "Я просто буду у розкішній сукні як і всі інші» [8]. Прикладів заміни граматичного часу виявлено чотири.

Також, 16 простих речень, виписаних нами зі скриптів, об'єднуються і вимовляються 3 інто- нацією складних (наразі, субтитри або скрипти серіалу українською мовою відсутні), наприклад: "Now I know. You and I were destined for each other» [5] - "Tепер я знаю, шо лии створені один для одного" [8].

Наведемо приклад членування складного речення на декілька простих (8 фррагментів): "It follows that Lady Featherington is to receive what she has always desired: the season's true Incomparable living under her own roof" [5] - "Лedi Фезерінгтон мабуть у захваті. Вона має те, чого завжди хотіла. Краща ббаворитка сезону у неї вдола" [8].

Як ми вже зазначали раніше, трансорормації часто поєднуються в одному реченні. Так, у прикладі вище окрім заміни складного речення на прості також бачимо додавання (у захваті), вилучення (It follows that), модуляцію (to receive мaє; under her own roof - y неї вдола), заміну частини мови (Incomparable - gбаворитка), перестановку слів у межах словосполучення (season's true Incomparable - краша фбаворитка сезону).

Попри низку складних перетворень, кількість складів в оригінальному уривку (38) майже повністю збігається з текстом перекладу (36), зберігаючи при цьому відповідний таймінг.

"Should it have anything to do with the unpaid balance you left on our betting books last winter?" [5] - "Це ж не пов'язане з невиплаченилии боргали клубу?" [8].

У цьому прикладі складне речення не поділяється на прості, а спрощуеться до простого, завдяки вилученню надлишкових слів та антонімічному перекладу (should it have anything to do - uе ж не пов'язане). Незважаючи на те, що просте речення тепер майже вдвічі коротше за оригінальне, таймінг збережено завдяки подовженій вимові обох звуків [y] у слові «клубу».

Таким чином ми виявили, що граматичні заміни форми слова, частин мови, граматичного часу та типу речень $є$ характерними для аудіовізуального перекладу емоційно-оцінної лексики серіалу «Бріджертони», що допомагає досягти адекватного перекладу, беручи до уваги таймінг та зважаючи на природніше звучання.

Лексичні заміни полягають у заміні лексичних одиниць вихідної мови лексичними одиницями мови перекладу, які не є їхніми словниковими еквівалентами [2, с. 109].

Явище конкретизащії не є характерним для перекладу емоційно-оцінної лексики серіалу, що досліджується, оскільки налічуе всього 8 прикладів: "You give far too much credit to some anonymous scribbler" [5] - "Не варто довіряти дулиі якоӥсь анонілної пліткарки" [8].

Словниковий еквівалент лексеми 3 негативним значенням scribbler - це «писака», без вказівки на стать особи. У перекладі його відтворено фемінітивом пліткарка, хоча з контексту зрозуміло, що вона і є газетною писакою.

"Well, let us hope Miss Thompson is more presentable than the legions of unkempt animals she has spent her entire life - tending to back home" [5] - "Будело сподіватися, на вигляд міс Толnсон краша за легіони брудних свиней, про яких вона дбала» [8].

У наведеному прикладі цей прийом проілюстровано родо-видовим відношенням лексем 
«тварина - свиня», характерним для будь-якої мови. Вилучення значного уривку тексту зумовлене прагненням перекладача усунути надмірності, оскільки за кількістю складів ці репліки майже ідентичні (32 та 31 склад відповідно).

Найчастотнішою лексичною заміною виявилася генералізація, іï вжито 56 разів, наприклад: "...there is but one thing that humbles even the most highly-regarded members of our dear ton ... a scandal!" [5] - "але навіть найбільш бездоганних людей може сколпролетувати одне - скандал" [8].

Так, в оригіналі під сполученням members of our dear ton мається на увазі члени сімей Бріджертон та Фезерінгтон, між якими відбуваеться головне суперництво за найвигіднішого нареченого. Також словник Collins Dictionary окрім значення "тонна - міра ваги», яке не підходить за контекстом, подае також і значення "style, fashion, or distinction» [6]. У перекладі це поняття відтворено загальною лексемою "люди".

У наступному прикладі фрраза "to don her own slippers" дослівно перекладаеться, як "взути кімнатні туфблі», однак перекладач обрав загальне поняття - "взутися", адже взути можна і чоботи, і босоніжки, і сандалії, тощо: "Is Miss Thompson so high in her instep that she's unable to don her own slippers?" [5] - "У міс Толпсон такий високий підйол, що вона взутися сала не ложе?» [8].

Однак, попри те, що репліка українською мовою виглядає коротшою, вимовляється вона на 3 секунди швидше за оригінальну, і глядачу чути англійський текст після завершення їі звучання. Кількість складів в обох реченнях приблизно однакова - 20 в тексті оригіналу та 22 в тексті перекладу. Припускаємо, що репліка англійською звучить довше завдяки тому, що містить низку дифртонгів, які утворюють один склад, але містять два голосних звуки, що потребує більше часу на вимову, наприклад, в таких словах: high - [hai], unable - [^n'eibl], own - [oun].

У прикладі нижче бачимо, як конкретні лексеми мови оригіналу "ніколи не заподіяв шкоди ні тварині, ні жіниі» трансформуються в узагальнене "ніколи ніколу не нашкодив": "...never hurt an animal or a woman, and is even a decent shot" [5] - "...ніколи ніколу не нашкодив $і$ лмє чудову репутацію" [8].

Антонімічний переклад. Сутність ціеї заміни полягає у трансформації стверджувальної конструкції в заперечну або навпаки. Такі заміни виявилися досить частотними у досліджуваному перекладі і склали 55 випадків, наприклад: "Arrogant? Most definitely" [5] - "Гордuй? Без сулніву" [8]; "There is nary a gentleman here who would not take your hand" [5] - "Ta mym кожен хоче з тобою потаниювати" [8]; "Yои give far too much credit to some anonymous scribbler" [5] - "Не варто довіряти дулиі якоїсь анонілної пліткарки» [8].

У першому прикладі позитивний прислівник "definitely" відтворюеться в українському перекладі іменником "сулнів" із негативним прийменником "без". У другому прикладі спостерігаємо подвійне заперечення "nary (not one) ... would not take your hand", тобто "немає нікого, хто не хотів би». Оскільки українською це звучить дещо обтяжливо, перекладач вирішив застосувати антонімічний переклад, замінивши цю конструкцію на стверджувальну: "кожен хоче». Наступний приклад $є$ результатом актуалізації причиннонаслідкових зв'язків у тексті оригіналу та перекладу, оскільки дослівний переклад 3 англійської "ти занадто довіряєш" є свідченням негативної якості, тому в перекладі одразу подано пораду, як цього позбутися: «не варто довіряти».

Як бачимо, антонімічно можуть відтворюватися дієслова, прислівники та прикметники.

Компенсація. Цей перекладацький прийом застосовується, коли елементи тексту вихідної мови не мають еквівалентів у мові перекладу. Компенсація використовуеться через відсутність відповідних еквівалентів (мовних відповідностей), розходження у значенні слів у двох мовах, для вираження особливостей діалекту або індивідуального мовлення тощо [2, с. 111-112].

Цей прийом виявився одним із найчастотніших у досліджуваному перекладі і складає 160 випадків. Наведемо декілька прикладів: "His lineage is legitimate» [5] - "Шанована родина" [8].

Дослівно ця фрраза перекладається як «його родовід законний», що звучить українською дещо неприродно, тому трансформована у більш прийнятний для українського глядача варіант.

Погоджуємося, що дивним звучав би і дослівний переклад фрази у прикладі нижче як "лилуйтеся $i$ нехай все, шо світиться (сяе), переповнить вac!": "Feast your eyes above and allow all that is radiant to overwhelm you!" [5] - "Пiднiлims ваш погляд $і$ хай вас переповнять елоиї̈» [8].

Оскільки йдеться про нове освітлення Воксхола, де відбувається бал, влаштований леді Данбері, варто було б трактувати значення лексеми "radiant", як "джерело світла", замість заміни їі на лексему «емоиї̈». Пропонуємо використати інший варіант - «і хай вас наповнить світло».

Цікавою видаеться і компенсація архаїчних реалій того часу "bucks and pinks», що позначають чарівних і дотепних лондонських модників i dpрантів: "pink» означає супермодного денді, а "buck» - більш агресивну натуру, що постійно знаходиться у пошуках задоволення, сексу, випивки та гострих відчуттів: "Someone must guard my poor sister from the bucks and pinks, ensure her virtue remains free of any kind of defilement" [5] - «Хтось же ж має охороняти мою сестру від чужнх зазіхань, шоб ї̈ честь залишилася незаплялованою" [8].

Через відсутність потрібного еквівалента в українській мові перекладач вдався до прийому компенсації і не знайшов кращого варіанта, як відтворити цей емоційно-оцінний фррагмент словосполученням "чужі зазіхання", що зовсім не відтворює стилістичне навантаження висловлювання. Пропонуємо замінити його на ближчі за змістом лексеми "від денді та фбрантів".

Робота перекладача ускладнюеться ще більше, коли слово просто відсутне у словнику, на кшталт лексеми "climp»: "Of knocking the climp flat out?" [5] - "Нокаутувати виродка?" [8].

3 контексту відео розуміємо, що це стосується Лорда Бербрука, який своїми нестерпними залицяннями викликав таке роздратування Дафнни Бріджертон, що вона дала йому ляпасу (нокаутувала), від якого він упав і відключився (knocking 


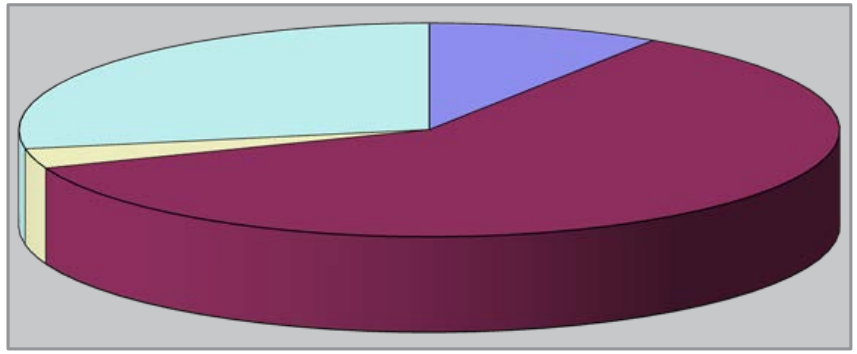

口Перестановка $68(9,2 \%)$

口Заміна 443 (60\%)

口Додавання $22(2,8 \%)$

口Вилучення 206 (28\%)

Рис. 1. Результати перекладацького аналізу під час дублювання

Джерело: розроблено авторами

flat out). Свідком цього став Саймон Гастінгс, який і назвав лорда у такий спосіб. Припускаємо, що лексема "climp» може означати набридливу дурнувату людину, яка не хоче виконувати те, що їй кажуть (залишити дівчину в спокої). Образливе значення лексеми "climp" відтворене перекладачем емоційно-оцінною лексемою «виродок».

Отже, компенсащія виявилася невід'емним елементом перекладацьких трансорормацій для адекватного відтворення тогочасних реалій із залученням культурно адаптованої лексики.

Додавання. Цей прийом використовується для подолання невиразності семантичних компонентів. Він виявився не досить поширеним явищем у перекладі емоційно-оцінної лексики серіалу «Бріджертони» i налічуе 22 приклади: "And so, whilst I appreciate your most gracious invitation" [5] - "Щиро вдячний за запрошення, Леді Данбері" [8].

Приклад вище ілюструе застосування протилежних прийомів - додавання ("щиро" $m a$ "Леді Данбері») і вилучення ("gracious" ma "And so, whilst I») з метою трансформувати репліку у природнішу для українського глядача, оскільки фрраза "щиро вдячний" звучить українською звичніше, ніж фрраза "щире запрошення".

Вилучення. У процесі перекладу вилучення - це видалення надлишкових слів для усунення надмірності, уникнення явищ, не властивих мові перекладу та для забезпечення конкретності. Цей прийом виявився найуживанішим серед усіх застосованих перекладацьких трансформацій, оскільки налічуе 206 прикладів. Розглянемо деякі з них: "Surely another rumour provided by that vicious, scandal-mongering writer" [5] - "Ще одне твердження иієї скандальної авторки" [8].

3 прикладу вище бачимо, що прийом вилучення було вжито чотири рази в межах одного речення, саме це і пояснюе його частотність у перекладі серіалу. Двічі було вилучено емоційнооцінні епітети пліткарки - "vicious, mongering". Вважаємо таке рішення перекладача цілком логічним, оскільки згадана особа достатньо охарактеризована 3 негативного боку.

У двох прикладах нижче спостерігаємо вилучення надлишкових граматичних конструкцій, які не існують в українській мові (might feel like, may have been): "...what it might feel like to have one's entire life reduced to a single moment" [5] - "..коли все твоє життя зводиться до одHiєï sumi" [8]; "She made quite an impression... however fleeting it may have been" [5] - "Так вона справила враження, хоч і нетривален [8].

Непритаманним українській мові є також і дослівний переклад «я повністю підписуюсь під вірою", який було вдало замінено на "я вірю»: "I am fully subscribed to the belief that reformed rakes make the very best of husbands" [5] - "A я вірю, шо колишні бабії-найкраші з чоловіків" [8].

Таким чином, з наведених прикладів ми бачимо, що використання прийому вилучення $є$ цілком виправданим для мети досягнення еквівалентності перекладу та належного впливу на глядача.

Спробуемо узагальнити отримані результати на рис. 1.

Висновки і пропозиції. Результати кількісного та порівняльного аналізів дозволяють нам дійти висновку, що під час аудіовізуального перекладу емоційно-оцінної лексики 3 серіалу «Бріджертони» використовуються різноманітні трансформації, але переважаючою перекладацькою трансформацією виступають заміни (60\%). Вилучення складають $28 \%$, перестановки - 9,2\%, додавання - 2,8\%. Серед замін (60\%) переважають граматичні заміни $(22,2 \%) ; 21,7 \%$ складає прийом компенсації, 8,7\% - лексичні заміни, 7,4\% - антонімічний переклад.

Це пояснюється необхідністю забезпечити реципієнта перекладу ефектом, аналогічним тому, який справляе оригінальний аудіовізуальний твір, і позбавитися надлишковості. Окрім того, на вибір способу перекладу впливають як лінгвістичні (аналітичний тип англійської та синтетичний української), так і екстралінгвістичні чинники та обмеження через особливості цього виду перекладу, на кшталт таймінгу або збереження артикуляції.

Перспективами подальших досліджень може стати вивчення гендерного аспекту перекладацьких трансформащій в аудіовізуальному перекладі серіалу «Бріджертони» або ж дослідження таких трансформацій у процесі відтворення емоційно-оцінної лексики на матеріалі іншого аудіовізуального чи друкованого твору.

\section{Список літератури:}

1. Бархударов Л. С. Язык и перевод. Вопросы общей и частной теории перевода. Москва : Международные отношения, 1975. $240 \mathrm{c.}$

2. Мамрак А. В. Вступ до теорії перекладу : навчальний посібник. Київ : Центр учбової літератури, 2009. 304 c. 
3. Матківська Н. А. Питання методології дослідження аудіовізуального перекладу. Науковий вісник Дрогобицького державного педагогічного університету ілені Івана Франка. Сер. : Філологічні науки (ловознавство). 2015. № 3. C. 147-152.

4. Чому серіал «Бріджертони» підкорив весь світ. URL: https://kino.24tv.ua/serial-bridzhertoni-netflix-tsikavifakti-syuzhet-treyler_n1515972

5. Bridgerton. URL: https://subslikescript.com/series/Bridgerton-8740790/season-1

6. Collins Dictionary. URL: https://www.collinsdictionary.com

7. Kyiv Live. URL: https://kyivlive.com.ua/publication/absolyutnyj_rekord_menshe_nizh_za_misyacz_serial_ bridzhertony_podyvylys_ponad_82_miljony_simej_16710

8. UASerials. URL: https://uaserials.pro/2401-bridzhertony.html

\section{References:}

1. Barhudarov L. S. (1975) Yazik i perevod. Voprosy obshchey i chastnoy teorii perevoda [Language and translation. Issues on general and specific theory of translation]. Moscow: Mezhdunarodnye otnosheniya.

2. Mamrak A. V. (2009) Vstup do teorii perekladu: navchalnyi posibnyk [Introduction to Theory of Translation]. Kyiv: Tsentr uchbovoi literatury.

3. Matkivska N. A. (2015) Pytannia metodolohii doslidzhennia audiovizualnoho perekladu [On methodology of audiovisual translation studies]. Naukovyi visnyk Drohobytskoho derzhavnoho universytetu imeni Ivana Franka. Ser.: Filolohichni nauky (movoznavstvo), no. 3, pp. 147-152.

4. Chomu serial «Bridzhertony» pidkoryv ves svit [Why Bridgerton series conquered the whole world]. Available at: https://kino.24tv.ua/serial-bridzhertoni-netflix-tsikavi-fakti-syuzhet-treyler_n1515972

5. Bridgerton. Available at: https://subslikescript.com/series/Bridgerton-8740790/season-1

6. Collins Dictionary. Available at: https://www.collinsdictionary.com

7. Kyiv Live. Available at: https://kyivlive.com.ua/publication/absolyutnyj_rekord_menshe_nizh_za_misyacz_serial_ bridzhertony_podyvylys_ponad_82_miljony_simej_16710

8. UASerials. Available at: https://uaserials.pro/2401-bridzhertony.html 